\title{
Segmentectomy for primer lung cancer, which arise from azygos lobe: azygos lobectomy
}
Hüseyin Fatih SEZER ${ }^{1}$
Galbinur ABDULLAYEV ${ }^{1}$
Adil AVCI ${ }^{1}$
Serkan ÖZBAY ${ }^{2}$
Salih TOPÇU ${ }^{1}$

${ }^{1}$ Department of Chest Surgery, Faculty of Medicine, Kocaeli University, Kocaeli, Turkey

${ }^{1}$ Kocaeli Üniversitesi Tıp Fakültesi, Göğüs Cerrahisi Anabilim Dalı, Kocaeli, Türkiye

2 Department of Chest Surgery, Faculty of Medicine, Giresun University, Giresun, Turkey

2 Giresun Üniversitesi Tıp Fakültesi, Göğüs Cerrahisi Anabilim Dalı, Giresun, Türkiye
Cite this arcticle as: Sezer $H F$, Abdullayev $G$, Avcl A, Özbay $S$, Topçu S. Segmentectomy for primer lung cancer, which arise from azygos lobe: azygos lobectomy. Tuberk Toraks 2019;67(3):231-3.

Yazışma Adresi (Address for Correspondence)

Dr. Hüseyin Fatih SEZER

Kocaeli Üniversitesi Tıp Fakültesi,

Göğüs Cerrahisi Anabilim Dalı,

KOCAELI - TÜRKIYE

e-mail: hfs.hfs@gmail.com

\begin{abstract}
Segmentectomy for primer lung cancer, which arise from azygos lobe: azygos lobectomy

The azygos lobe is a rare congenital anomaly of the right upper lobe of the lung. There are few surgical cases that azygos lobectomy reported arise from an azygos lobe primary lung cancer in the literature. We share our treatment experience in our case who a 65-year-old male and he has a primary lung cancer arise from azygos lobe. Lung cancer surgery principiles for segmentectomy (azygos lobectomy) can be performed it by avoiding complications.

Key words: Azygos lobe; lobectomy; lung cancer

ÖZ

Azigos lob kaynaklı primer akciğer kanserine yapılan segmentektomi: azigos lobektomi

Azigos lob, sağ akciğer üst lobunun nadir görülen bir doğuştan anomalisidir. Literatürde primer azigos lob kaynaklı akciğer kanseri nedeniyle azigos lobektomi yapılan bildirilmiş birkaç olgu vardır. Yazımızda azigos lobundan kaynaklı primer akciğer kanseri olan 65 yaşındaki erkek hastadaki tedavi deneyimimizi paylaşıyoruz. Komplikasyonlardan kaçınarak akciğer kanseri cerrahi prensipleri segmentektomi (azigos lobektomi) için gerçekleştirilebilir.
\end{abstract}

Anahtar kelimeler: Azigos lob; lobektomi; akciğer kanseri 


\section{INTRODUCTION}

The azygos lobe is a rare congenital anomaly of the right upper lobe of the lung (1-3). Its prevalans $1 \%$ of the general population $(1,2)$. Generally it is detected incideantaly on the X-ray or computed tomography (CT). There are few surgical cases reported primary an azygos lobe lung cancer in the literature (4-6). In this presentation, we share our treatment experience in our case of lung cancer limited in azygos lobe.

\section{CASE REPORT}

A 65-year-old male presented upper respiratory tract infection and cough. Chest X-ray bring to light an azygos lobe and increased opacity in the azygos lobe. Thorax Computed Tomography (CT) and Positron Emission Tomography (PET/CT) imaging described a 2 $\mathrm{cm} \times 2 \mathrm{~cm}$ diamater speculated lesion in an azygos lobe (SUVmax: 5) (Figure 1). For a definite diagnosis of the tumor transthoracic needle biopsy was performed. Histopatologic result of CT-guided transthoracic biopsy was consistent with the primary lung cancer (adenocarcinoma). Pulmonary function tests were appropriate for lung resection; Forced expiratory volume $\left(\mathrm{FEV}_{1}\right)$ was $2.93 \mathrm{~L}$ and diffusing capacity of lung for carbon monoxide (DLCO) was $74 \mathrm{~mL} /$ $\mathrm{mmHg} / \mathrm{min}$. Was taken desicion to perform azygos lobectomy. Posterolateral thoracotomy incision was performed. The azygos vein was seen to course over the azygos lobe. Azygos lob vein and arter were dissected, both of them roped than cuted. Afterwards right upper lob apical segment bronchus (azygos lobe bronchus) visualised (Figure 2), cuted and primary closed with 3/0 polipropilen sutures. Divide azygos lobe from right upper lobe by a linear stapler. Lymph node dissection was performed. Final pathologic staging was, T1a, N0, M0. The patient had no complication during follow-up and he was discharged home on the six postoperative day.

\section{DISCUSSION}

The azygos lobe is a rare congenital anomaly of the right upper lobe of the lung (1-3). Its prevalans $1 \%$ of the general population $(1,2)$. Generally it is detected incideantaly on the X-ray or CT in the some patient population who applied due to another system symptoms. Azygos lobe was found in $0.4 \%$ chest $\mathrm{X}$-ray and in $1.2 \%$ of $\mathrm{CT}$ in radiological examinations and in a limited study conducted in our country, this rate was found to be higer as $1.54 \%$ in the CT scans (3). In
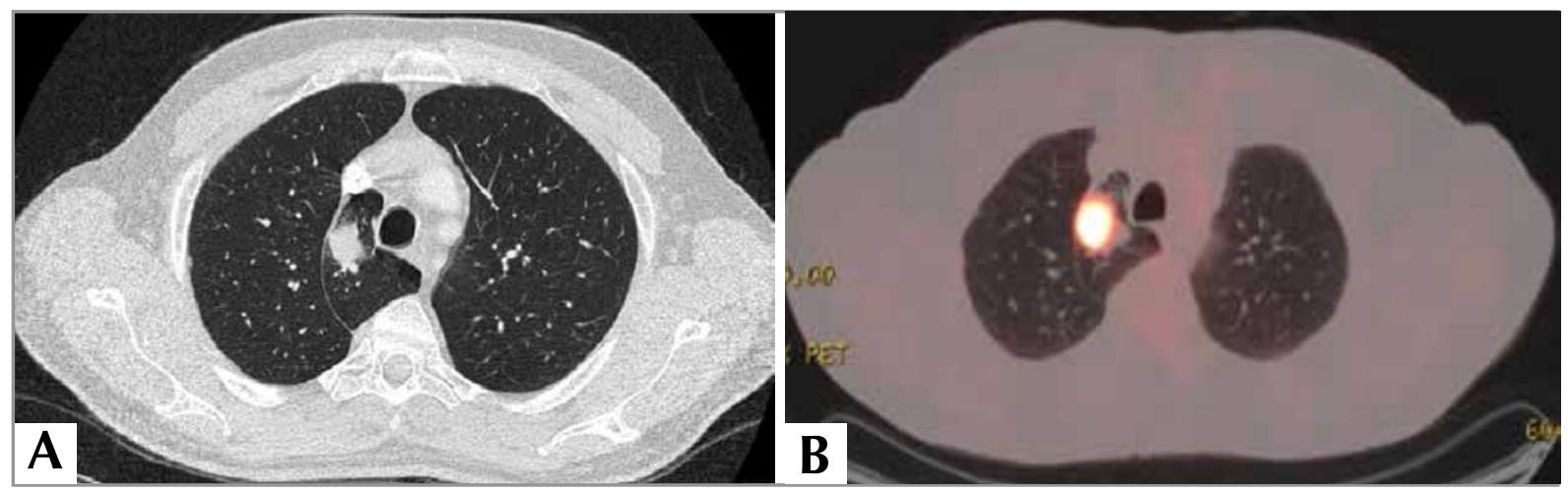

Figure 1. A. Thorax CT scan, B. PET-CT scan.
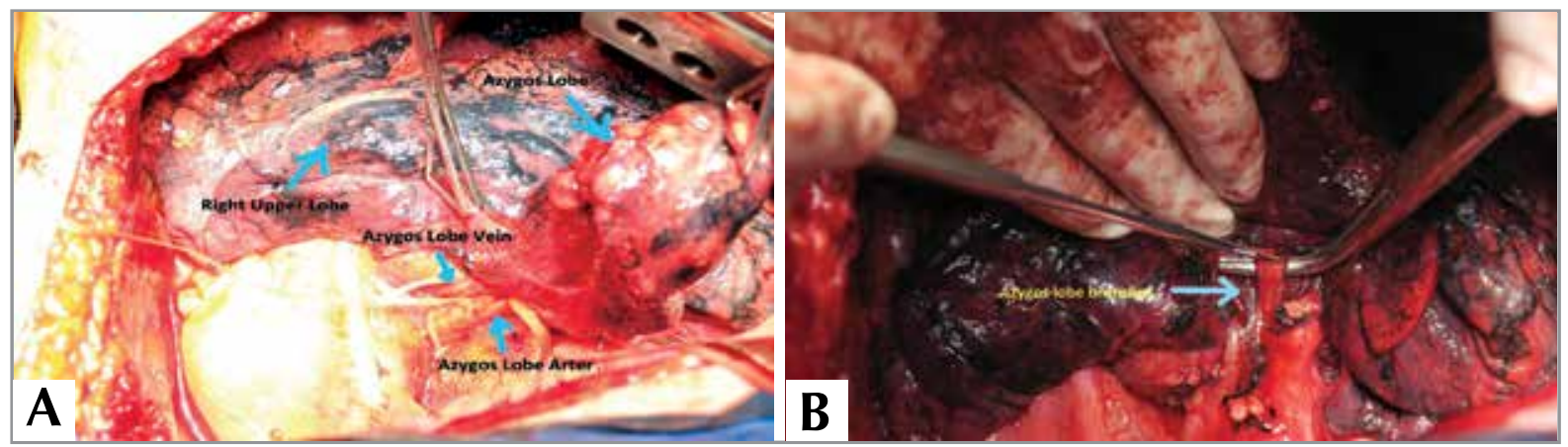

Figure 2. A. Azygos lobe vein and arter, B. Azygos lobe bronchus. 
patients with azygos lobes may be observed other systems anomalies but our patient has not.

There is not enough data about the incidence of non small cell lung cancer that arising in an azygos lobe in the literature. There are few azygos lobectomycases reported primary an azygos lobe lung cancer in the literature (4-6). We performed an azygos lobectomy that arising in azygos lobe for non-small cell lung cancer. Some studies repoerted that non-small cell lung cancer which arising in an azygos lobe is not associated with regional lymph node involvement as our case (1).

The surgical is gold standard for the treatment of patients who early stage non-small cell lung cancer and functional operative (7). Segmentectomy shows similar outcomes compared to lobectomy for stage 1a non-small cell lung cancer (8). And some studies show that segmentectomy may be adequate even for tumours less than $2 \mathrm{~cm}$ in size extended lymph node dissection $(7,8)$. Although the pulmonary function values of the patient were enough for lobectomy, we decided on segmentectomy due to the size of the tumor and there is not any metastatic lymph node during the lymph node dissection.

Primary lung cancer surgery treatment (azygos lobectomy) which arising from azygos lobe is a rare condition. Lung cancer surgery principiles for segmentectomy can be performed it by avoiding complications.

\section{CONFLICT of INTEREST}

No conflict of interest declared by the authors.

\section{AUTHORSHIP CONTRIBUTIONS}

Concept/Design: All of authors.

Analysis/Interpretation: All of authors.

Data Acquisition: All of authors.

Writting: All of authors.

Critical Revision: All of authors.

Final Approval: All of authors.

\section{REFERENCES}

1. Kotov G, Dimitrova IN, Iliev A, Groudeva V. A rare case of an azygos lobe in the right lung of a 40-year-old male. Cureus 2018

2. Marco N, Alessandra C, Francesco B, Marcello M. A unique case of lung cancer invading azygos lobe and vein. Medical Case Reports 2018;4.

3. Ozdemir L, Ozdemir B, Duman T. Prevalence of an azygos lobe using thoracic computed yomography. Cyprus Journal of Medical Sciences 2017;1:55-7.

4. Kawasaki H. Partial anomalous pulmonary venous connection coexisting with lung cancer: a case report and review of relevant cases from the literatüre. Annals of Thoracic and Cardiovascular Surgery 2017;23:31-5.

5. Papiashvili M, Hayat H, Schreiber L, Priel IE. Thoracoscopic azygos vein lobe resection in a patient with synchronous right and left lung cancer. Isr Med Assoc J 2015;17:387-8.

6. Shakir HA. Removal of aberrant azygos lobe containing positron emission tomography positive nodule with the use of video-assisted thoracic surgery. International Journal of Surgery Case Reports 2014;5:95-6.

7. McDonald F, De Waele M, Hendriks LEL, Faivre-Finn C, Dingemans AMC, Van Schil PE. Management of stage I and II nonsmall cell lung cancer. Eur Respir J 2017;49:1600764.

8. Roman M. Lobectomy vs. segmentectomy. A propensity score matched comparison of outcomes. Eur I Surg Oncol 2019;45:845-50. 